\title{
Effectiveness of Bintaro Seeds Extract (Cerbera odollam Gaertn.) on Armyworm (Spodoptera litura (Fabricius) Mortality
}

\author{
Mery Sintia Dewi ${ }^{1)}$, Wachju Subchan ${ }^{1)} \bowtie$, Jekti Prihatin ${ }^{1)}$ \\ ${ }^{1}$ Biology Education, Faculty of Teacher Training and Education, University of Jember \\ email:wachju.fkip@unej.ac.id
}

\begin{abstract}
Armyworm (Spodoptera litura (Fabricius) often lead to decreased productivity and even crop failures by causing leaves, fruits, and vegetables to become torn, cut, and punctured. Crop insecticides are an alternative to eradicating armyworm (Spodoptera litura (Fabricius). One plant that can be used as a vegetable insecticide is bintaro (Cerbera odollam Gaertn.) The bintaro plant (Cerbera odollam Gaertn.) has cerberin content that contribute to insect mortality. This study aims to determine the effectiveness of extract (Cerbera odollam Gaertn.) on mortality of armywork (Spodoptera litura (Fabricius). This study was a type of experiment using Completely Randomized Design (CRD) with five treatments and one control. The results showed that the effectiveness of seeds bintaro extract (Cerbera odollam Gaertn.) could cause death to armyworm (Spodoptera litura (Fabricius) on 1.5\% concentration of 55\% showed effective on the armyworm. Increasing the dose is to be followed by increasing the effectiveness of mortality. The $L_{50}$ value is $1.51 \%$. Increasingly concentration of seeds bintaro extract (Cerbera odollam Gaertn.) cause higher mortality of armyworm (Spodoptera litura (Fabricius).
\end{abstract}

Keywords: Spodoptera litura (Fabricius), Cerbera odollam Gaertn. Seeds Extract, Mortality

\section{INTRODUCTION}

The diversity of insects in Indonesia consists of 151,847 species or about $15 \%$ of the total number of biota [1], some of them known as pests on food crops and horticulture. One of pests that attacks and harms food crops and horticulture is armyworm (Spodoptera litura (Fabricius) [2].

Spodoptera litura (Fabricius) often leads to a decrease in productivity and even crop failure because it causes leaves, fruits, and vegetables to become torn, cut into pieces, and potholes. If it not immediately tacled then the leaves or fruit plants in agricultural areas will be gone [3]. Loss of results due to pest attack can reach $85 \%$ and can even cause crop failure [4].

Spodoptera litura (Fabricius) make farmers lose their crops, so this pest should controlled to increase crop and horticulture production. To control pests of plant diseases, farmers generally prefer to apply insecticides because it considered very effective, practical, and fast in killing pests [2]. Incorrect and excessive use of synthetic insecticides has resulted in the formation of insecticide resistance to various insecticides [5 and 6]. Plant-based insecticides do not cause pest resistance quickly [7].

Vegetable insecticides are an alternative to eradicate Spodoptera litura (Fabricius) pests [6 and 8]. The use of vegetable Insecticides is safer than synthetic insecticides because it will more easily decompose naturally by nature. Vegetable insecticide is define as an insecticide that use plant as it base material [9].

Cerbera odollam Gaertn is one of the species of mangrove-group plant that spread fairly wide in Indonesia [10]. Cerbera odollam Gaertn's fruit is a drupa fruit (grain fruit) that physically has fibers like coconut. Cerbera odollam Gaertn included non-food crops due to poison content on Cerbera odollam Gaertn seeds which made this fruit not edible [11].

Cerbera odollam Gaertn plant has cerberin contents that contribute to insect mortality [12]. Cerbera odollam Gaertn

Bioedukasi Vol. XVI. No.1 April 2018

Received 11 Maret 2018 | Received in revised form 5 April 2018| Accepted 13 April 2018| Published online 31 April 2018 
seeds contains toxins that can cause severe shortness of breath even in high doses can kill animals or humans [13].

Cerbera odollam Gaertn seeds has the highest level of toxicity compared to the leaves and fruit. Cerbera odollam Gaertn seeds contains some secondary metabolite compounds that have an effect on insect mortality such as cerberin, tannin, saponin, and alkaloids [14].

Saponins can bind sterols in the food, in can decreasing the rate of sterols in hemolimfa. The sterol role for Spodoptera litura (Fabricius) is as the ekdison hormone precursor. Decrease in sterol supply is inhibit the process of insect skin change, so that inhibiting its growth and development [13].

Based on the fact the seeds of Cerbera odollam Gaertn is effectively used as a vegetable insecticide, it is necessary to conduct a further research on the effect of bintaro seeds extract (Cerbera odollam Gaertn.) on the mortality of armyworm (Spodoptera litura (Fabricius).

\section{RESEARCH METHOD}

Experimental research using Completely Randomized Design (CRD). In this study, it is used five levels of treatment and one control. Each treatment and control use four replications. Each repetition contains ten Spodoptera litura (Fabricius) instar III.

The analyzed data in this research is the percentage of larval mortality calculated by using Abbots' formula as follows [15].

Note:

$$
\mathrm{P}=\frac{\mathrm{P} *-\mathrm{C}}{1-\mathrm{C}}
$$

$\mathrm{P}$ : Experimental treatment response which is corrected for the control response

$\mathrm{P}^{*}$ : Experimental treatment response

$\mathrm{C}$ : Control response

Analysis of the effectiveness of bintaro seeds extract (Cerbera odollam Gaertn.) On armyworm (Spodoptera litura
(Fabricius) mortality can be searched by the following formula.

Survivorship $\%=\frac{\text { Survivorship end }}{\text { Survivorship start }} \times 100$

Value of Mortality Effectiveness \%

$=$ Survivorship $_{\text {control }}-$ Survivorship $_{\text {treatment }}$

Table 1. Assessment of effectiveness criteria

\begin{tabular}{ll}
\hline Category & Score \\
\hline Very effective & $75-100 \%$ \\
\hline Effective & $50-74,9 \%$ \\
\hline $\begin{array}{l}\text { Effective } \\
\text { enough }\end{array}$ & $25-49,9 \%$ \\
\hline Not effective & $<25 \%$ \\
\hline
\end{tabular}

Data analysis to determine the killing power of bintaro seeds extract (Cerbera odollam Gaertn.) On armyworm (Spodoptera litura (Fabricius) in the form of $\mathrm{LC}_{50}$ is using probit analysis with minitab software version 14.

\section{RESULT AND DISCUSSION}

a. Uji Homogeneity test in this research is measuring the weight of armyworm in order to have the same variation. Homogeneity test results of 0.992 showed that the weight of armyworm before bintaro seeds extract treatment was not significantly different.

b. Spodoptera litura (Fabricius) Mortality

Mortality in this study was the number of Spodoptera litura (Fabricius) deaths during the study calculated in terms of percent. The mean percentage mortality of Spodoptera litura (Fabricius) showed in Figure 1. 


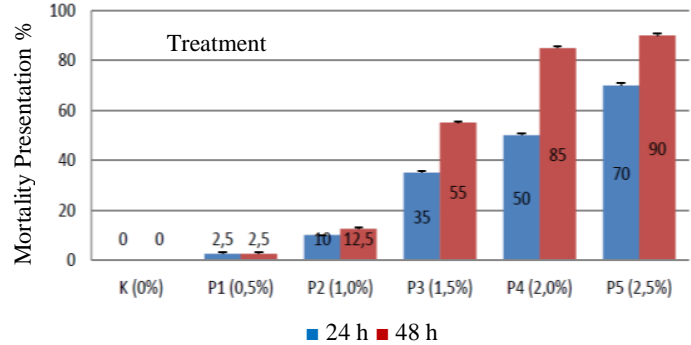

Figure 1. Histogram average percentage mortality of Spodoptera litura (Fabricius) on bintaro seeds extract treatment with dedup time of 24 hours and 48 hours

From Figure 1. it can be seen that mortality of Spodoptera litura (Fabricius) with dedup time of 24 hours from the largest to the smallest is P5 $(2,5 \%)$ by $70 \%$, $\mathrm{P} 4(2.0 \%)$ is $50 \%, \mathrm{P} 3(1.5 \%)$ by $35 \%, \mathrm{P} 2$ $(1.0 \%)$ by $10 \%, \mathrm{P} 1(0.5 \%)$ by $2.5 \%$ and $\mathrm{P} 0$ $(0 \%)$ by $0 \%$. While mortality of Spodoptera litura (Fabricius) with time dedup of 48 hours from the biggest to smallest respectively that is $\mathrm{P} 5(2,5 \%)$ equal to $90 \%$, P4 (2.0\%) equal to $85 \%, \mathrm{P} 3(1,5 \%)$ by $55 \%$, P2 $(1.0 \%)$ by $12.5 \%, \mathrm{P} 1(0.5 \%)$ by $2.5 \%$ and $\mathrm{P} 0(0 \%)$ by $0 \%$.

Lethal Consentration $\left(\mathrm{LC}_{50}\right)$ is expressed as a concentration of insecticide that can kill half of the animal population after a certain period of time. Based on the probit analysis that has been done by using minitab software version 14 , it can be seen the value of $\mathrm{LC}_{50}-48$ hours in Table 2 .

Table 2. $\mathrm{LC}_{50}$ value, upper limit and lower limit of bintaro seeds extract with a dedup time of 48 hours

\begin{tabular}{llll}
\hline Treatment & $\begin{array}{l}\text { LC }_{50} \\
\text { Value } \\
(\%)\end{array}$ & $\begin{array}{l}\text { Lower } \\
\text { Limit } \\
(\%)\end{array}$ & $\begin{array}{l}\text { Upper } \\
\text { Limit } \\
(\%)\end{array}$ \\
\hline $\begin{array}{l}\text { Bintaro } \\
\text { Seeds } \\
\text { Extract }\end{array}$ & 1,51 & 1,36 & 1,64 \\
\hline
\end{tabular}

From Table 2. it can be seen that the value of $\mathrm{LC}_{50}-48$ hours is $1.51 \%$ with a carrying limit of $1.36 \%$ and the upper limit of $1,64 \%$. c. Effectiveness of bintaro seeds extract (Cerbera odollam Gaertn.) on mortality of Spodoptera litura (Fabricius)

The effectiveness of bintaro seeds extract (Cerbera odollam Gaertn.) on mortality of Spodoptera litura (Fabricius) showed in Table 3 below.

Table 3. Effectiveness of bintaro seeds extract (Cerbera odollam Gaertn.) on mortality of Spodoptera litura (Fabricius)

\begin{tabular}{lll}
\hline Treatment & $\begin{array}{l}\text { Effectiveness } \\
\text { Value }\end{array}$ & Note \\
\hline P1 $(0,1 \%)$ & $2,5 \%$ & $\begin{array}{l}\text { Not } \\
\text { Effective }\end{array}$ \\
\hline P2 $(1,0 \%)$ & $12,5 \%$ & $\begin{array}{l}\text { Not } \\
\text { Effective }\end{array}$ \\
\hline P3 (1,5\%) & $55 \%$ & Effective \\
\hline P4 (2,0\%) & $85 \%$ & $\begin{array}{l}\text { Very } \\
\text { Effective }\end{array}$ \\
\hline P5 (2,5\%) & $90 \%$ & $\begin{array}{l}\text { Very } \\
\text { Effective }\end{array}$ \\
\hline
\end{tabular}

From Table 3. Can be concluded that the effectiveness of bintaro seeds extract (Cerbera odollam Gairtn.) on Spodoptera litura (Fabricius) mortality in the first treatment and the second treatment is in not effective category. The third treatment fall into the effective category. The fourth and fifth treatments fall into very effective categories. The effectiveness of bintaro seeds extract (Cerbera odollam Gairtn.) on Spodoptera litura (Fabricius) mortality was effective in the third treatment with concentration of $1.5 \%$ to the fifth treatment with concentration of $2,5 \%$.

d. TLC test (Thin Layer Chromatography) Bintaro Seeds Extract (Cerbera odollam Gaertn.) as Supported Data

TLC (Thin Layer Chromatography) is a test used in this study to detect a compound. The TLC test showed in Table 4. 
Table 4. TLC (Thin Layer Chromatography) bintaro seeds extract (Cerbera odollam Gaertn.)

\begin{tabular}{|c|c|c|c|c|}
\hline \multirow{3}{*}{$\begin{array}{l}\text { Binta } \\
\text { ro } \\
\text { Seeds } \\
\text { Extra }\end{array}$} & \multicolumn{4}{|c|}{ Type of Test } \\
\hline & $\begin{array}{l}\text { Alkalo } \\
\text { id }\end{array}$ & $\begin{array}{l}\text { Flavon } \\
\text { oid }\end{array}$ & $\begin{array}{l}\text { Sapon } \\
\text { in }\end{array}$ & $\begin{array}{l}\text { Tani } \\
\mathrm{n}\end{array}$ \\
\hline & + & - & ++ & + \\
\hline
\end{tabular}

Note

$+\quad$ : There is a little

$+\quad$ : There is much

- $\quad$ : None

From Table 4. it can be seen that bintaro seeds extract (Cerbera odollam Gairtn.) has a content of secondary metabolite compounds namely alkaloids, saponins, and tannins. Bintaro seeds extract (Cerbera odollam Gairtn.) contains no flavonoids.

The effectiveness of bintaro seeds extract (Cerbera odollam Gaertn.) showed from its effect on the armyworm (Spodoptera litura (Fabricius) used as test insects. The sample of Spodoptera litura (Fabricius) is obtained from BALITTAS Malang. Mortality is the parameter in this research. Mortality Spodoptera litura (Fabricius) is used to determine the magnitude of $\mathrm{LC}_{50}-48$ hours.

The application of bintaro seeds extract was done after measuring the weight of each armyworm. The armyworm weight data obtained was tested first with homogeneity test to know whether the data has been normal distributed or not. In the test, there is a significance value of 0.992 , which means the data normally distributed.

Based on the result of the research, we found that giving bintaro seeds extract has an effect on mortality of Spodoptera litura (Fabricius). From the data obtained, it showed that treatment at all levels of concentration found the death of Spodoptera litura (Fabricius) except control $(0 \%)$ no death. At figure 1 , it showed the effect of armyworm mortality on various concentrations. The addition of bintaro seeds extract concentration caused an increase in armyworm mortality. The higher the concentration of bintaro seeds extract is the higher the mortality rate of Spodoptera litura (Fabricius).

The chemical content contained in bintaro seeds can be used as a plant-based insecticide against mortality of Spodoptera litura (Fabricius). Bioactive compounds are always toxic at high doses. Any chemical compound including the active compound of the plant is essentially toxic, depending on the use, the dosage, the preparation, and the mode of use [16]. The entry of secondary metabolite compounds into the body of the larvae can damage the larvae organ system and inhibit larval activity. The content of secondary metabolic compounds causes the death of larvae [17].

Bintaro seeds extract caused Spodoptera litura (Fabricius) mortality increasing in every concentration. At $0.5 \%$ concentration, it can kill Spodoptera litura (Fabricius) of $2.5 \%$ with average mortality of 0.25 tail. $1.0 \%$ concentration is capable of killing Spodoptera litura (Fabricius) by $12.5 \%$ with an average mortality of 1.25 birds. $1.5 \%$ concentration is capable of killing Spodoptera litura (Fabricius) by $55 \%$ with average mortality of 5.5 . Concentration of $2.0 \%$ can kill Spodoptera litura (Fabricius) by $85 \%$ with average mortality of 8.5 tail. $2.5 \%$ concentration can kill Spodoptera litura (Fabricius) by $90 \%$ with average mortality of 9 tail. While in the control treatment, there is no death Spodoptera litura (Fabricius).

The effectiveness percentage of bintaro seeds extract (Cerbera odollam Gaertn.) on the mortality of Spodoptera litura (Fabricius) known by means of survivorship control minus the survivorship of treatment. From the calculation, the effectiveness of bintaro seeds extract (Cerbera odollam Gaertn.) to Spodoptera litura (Fabricius) mortality on one treatment with $0.5 \%$ concentration of $2.5 \%$ classified as ineffective category. The second treatment with a concentration of $1.0 \%$ of $12.5 \%$ belongs to the category of ineffective. The third treatment with a 
concentration of $1.5 \%$ that is equal to $55 \%$ belongs to the category effective. The forth treatment with a concentration of $2.0 \%$ of $85 \%$ belongs to the category of highly effective and the fifth treatment with a concentration of $2.5 \%$ that is $90 \%$ belongs to the category of very effective.

Based on probit minitab analysis version 14 , it showed that bintaro seeds extract had strong insecticidal activity on Spodoptera litura (Fabricius) with LC50 value was $1.51 \%$ with lower limit of $1.36 \%$ and upper limit of $1.64 \%$. This means that to get the death of armyworm by $50 \%$ by using bintaro seeds extract is not less than $1.36 \%$ and not more than $1.64 \%$. Bintaro leaf extract has a strong toxic effect on Spodoptera litura (Fabricius) both instar two and three [18]. Seeds extract was stronger in causing death of larvae with a percentage mortality of $90 \%$ [12].

The death on Spodoptera litura (Fabricius) caused by the toxic effects possessed by bintaro seeds extract that can enter the body of the larva through two ways: stomach poison and contact poison. Stomach poison is a type of insecticide that eaten by insects and kills the insect in particular by destroying or absorbing the digestive system. Contact poison is a type of insecticide that is absorbed through the body wall so that the insect must feel direct contact with the insecticide.

Based on the results of TLC (thin layer chromatography) test on bintaro seeds extract, it was found that bintaro seeds extract contained several secondary metabolite compounds namely alkaloids, saponins and tannins. Bintaro seeds extracts also tested for flavonoids, but there is no such compounds found in bintaro seeds extract. Bintaro seeds contain several substances such as alkaloids, saponins, tannins, and cerberins [14].

Alkaloids are toxic to larvae causing death of test larvae. Alkaloids are salt so they can degrade cell membranes to enter and damage cells [19]. Alkaloids can cause irritation of the digestive tract by damaging the peritrophic membranes of the larvae gastrointestinal tract [5].

How alkaloid works is to act as a stomach poisoning. If the compound enters the body of the larvae then its digestive apparatus will be disrupted [20]. Inclusion of toxic compounds into the body of the larvae will disrupt the body's metabolism of Spodoptera litura (Fabricius) larvae. This causes the energy-deficient larvae required for its life activity, convulsions and gradually causes the larvae to die.

Saponin is one of the most toxic compounds to insects [12]. Saponins have properties such as detergents that are considered being capable of increasing penetration of toxic substances because it can dissolve lipophilic material. How saponin works is acting as a contact poison that affects the nervous system. Contact poison enters the body of the Spodoptera litura (Fabricius) larvae through the cuticle or directly related to bintaro seeds extract. Toxic compounds entering the body of the larvae interfere with the nervous system by inhibiting the action of acetylcholinesterase enzyme [19]. The acetylcholinesterase enzyme serves to solve acetylcholine into choline, acetic acid, and water [21]. When acetylcholine is accumulated, subsequent impulse delivery can't be transmitted to the brain and the larvae experience seizures continuously until paralysis and even death.

Tannin is a polyphenol compound that can form complex compounds with proteins. How tannin works is as a stomach poison. Tannins can't be digested and have a binding capacity with proteins, carbohydrates, vitamins and minerals [22]. Tannins can bind on lipids and proteins and can bind protease enzymes that play a role in catalyzing proteins into amino acids which is necessary for the growth of larvae. Binding of the enzyme by tannin, causing the work of the enzyme inhibited, so that the cell metabolism process disturbed and the larvae will be lack of nutrients. As a result, the growth of larvae is inhibited and if this process continues, it will kill the larvae [23]. 
Cerberin belongs to a class of alkaloids or glycosides which thought to play a role in larval death [12]. Cerberin is an $\mathrm{N}$-free glycoside, which acts as a very powerful cardiac toxin [24]. Cerberin has toxic properties because it can disrupt the calcium ion channel inside the heart muscle of the larvae [25]. Cerberin can poison and damage the central nervous brain of mice. Cerberin swallowed by a rat causes the rat's heartbeat to stop [24].

The development and growth of Spodoptera litura (Fabricius) influenced by several factors, namely internal factors and external factors. Internal factor in this research is a factor caused from the body Spodoptera litura (Fabricius) such as chemical factors, morphological, and physiological. While external factor in this research is a factor that comes from outside the body Spodoptera litura (Fabricius) such as temperature and humidity of air. Temperature and humidity of the room in this study used room temperature. Temperature and humidity in this study were not controlled but measured to determine if there is a change in temperature and humidity at the time of the research.

Measurements of temperature and humidity shows that the average of room temperature equal to $31 \pm 30-32{ }^{\circ} \mathrm{C}$ and room humidity equal to $68 \pm 67-69 \%$. Based on these measurements, it known that external factors have no effect on the mortality rate of Spodoptera litura (Fabricius). Maintenance and propagation of Spodoptera litura (Fabricius) on laboratory environmental conditions temperature of $24.5-32{ }^{\circ} \mathrm{C}$, humidity of 65 $85 \%$ [26]. This is in accordance with control treatment with concentration of bintaro seeds extract at $0 \%$ indicating the total mortality of Spodoptera litura (Fabricius) by $0 \%$.

\section{CONCLUSION}

The effectiveness of bintaro seeds extract (Cerbera odollam Gaertn.) which can cause death to armyworm (Spodoptera litura (Fabricius) is effective at concentration $1.5 \%$ with $55 \%$ showed effective on the armyworm. The increased concentrations above $1.5 \%$ followed by increased effectiveness. $\mathrm{LC}_{50}$ value of $1.51 \%$. Increasingly concentration of seeds bintaro extract (Cerbera odollam Gaertn.) cause higher mortality of armyworm (Spodoptera litura (Fabricius).

\section{REFFERENCE}

[1] Badan Perencana Pembangunan Nasional. 2017. Biodiversity Action Plan for Indonesia. Jakarta: BAPPENAS.

[2] Sa'diyah, N.A., Purwani, K.I., dan Wijayawat, L. 2013. Pengaruh Ekstrak Daun Bintaro (Cerbera odollam) Terhadap Perkembangan Ulat Grayak (Spodoptera litura F.). Jurnal Sains dan Seni Pomits, $2(2)$.

[3] Wahyu, B. dan Indah, K. 2016. Pengaruh Ekstrak Daun Belimbing Wuluh (Averrhoa bilimbi) terhadap Mortalitas dan Perkembangan Larva Spodoptera litura. Jurnal Sains dan Seni ITS, 5 (2): 2337-3520.

[4] Tarigan, B., Syahrial, dan Tarigan, M.N. 2013. Uji Efektivitas beauveria basianna dan Bacillus thuringiensis terhadap Ulat Api (Setothosea asigna Eeck, Lepidoptera, Limacodidae) di Laboratorium. Jurnal Online Agroekoteknologi 1 (4).

[5] Ambarningrum, T. B., Pratiknyo, H. dan Priyanto S. 2009. Indeks Nutrisi dan Kesintasan Larva Spodoptera litura F. yang diberi Pakan Mengandung Ekstrak Kulit Jengkol (Pithecellobium lobatum Benth.). J. HPT Tropika. 9 (2): 109-114. 
[6] Triana, Linda. 2016. Resistensi Hama Ulat Grayak (Spodoptera Litura F.) Filial 1 terhadap Insektisida Botani Azadirachtin serta Pemanfaatanya sebagai Buku Ilmiah Populer. Skripsi. Jember: Universitas Jember.

[7] Hendrival, Latifah, dan Nisa, A. 2013. Efikasi Beberapa Insektisida Nabati untuk Mengendalikan Hama Pengisap Polong di Pertanaman Kedelai. Jurnal Agrista, 17 (1).

[8] Rahmawati, A. 2016. Resistensi Hama Ulat Grayak (Spodoptera litura F.) terhadap Insektisida Botani Azadirachtin dan Pemanfaatannya sebagai Buku Ilmiah Populer. Skripsi. Jember: Fakultas Keguruan dan Ilmu Pendidikan Universitas Jember.

[9] Syakir, M. 2011. Status Penelitian Pestisida Nabati Pusat Penelitian dan Pengembangan Tanaman Perkebunan. Semnas Pesnab IV.

[10] Handayani, R., Rukminita, S., dan Gumilar, I. 2015. Karakteristik Fisiko-Kimia Minyak Biji Bintaro (Cerbera manghas L.) dan Potensinya sebagai Bahan Baku Pembuatan Biodiesel. Jurnal Akuatika, IV (2).

[11] Iman, G., dan Handoko, T. 2011. Pengolahan Buah Bintaro sebagai Sumber Bioetanol dan Karbon Aktif. Prosiding Seminar Nasional Teknik Kimia "Kejuangan".

[12] Utami, S. 2010. Aktivitas Insektisida Bintaro (Cerbera odollam Gaertn) Terhadap Hama Eurema spp. pada Skala Laboratorium. Jurnal Penelitian Hutan Tanaman 7 (4): 211-220.
[13] Thamrin, M. dan Balai, S.A. 2014. Ekstrak Tumbuhan Kehutanan sebagai Insektisida Nabati. Prosiding Seminar Nasional Pertanian Ramah Lingkungan Mendukung Bioindustri di Lahan Sub Optimal Palembang.

[14] Prayuda, Y.E. 2014. Efikasi Ekstrak Biji Bintaro (Cerbera manghas) sebagai Larvasida pada Larva Aedes aegypti L. Instar III/IV. Skripsi. Jakarta: UIN Syarif Hidayatullah.

[15] Finney, D. J. 1971. Probit Analysis, 3rd ed. London; Cambridge University Press.

[16] Rizal, S. Dan Hanjani, S. 2014. Pengaruh Serbuk Daun Rimau (Toona sinensis Roem.) terhadap Kematian Larva Ulat Grayak (Spodoptera litura F.). Sainmatika, 11 (1).

[17] Yudha, H.W. 2013. Efektivitas Ekstrak Buah Bintaro (Cerbera odollam) sebagai Larvasida Lalat Rumah (Musca domestica). Skripsi. Bogor: Institut Pertanian Bogor.

[18] Utami, S., Syaufina, L., dan Haneda, N.F. 2010. Daya Racun Ekstrak Kasar Daun Bintaro (Cerbera Odollam G.) terhadap Larva Spodoptera Litura F. Jurnal Ilmu Pertanian Indonesia, 15 (2).

[19] Cania, E. Dan Setyaningrum, E. 2013. Uji Efektivitas Larvasida Ekstrak Daun Legundi (Vitex trifolia) terhadap Larva Aedes aegypti. Medical Journal of Lampung University, 2 (4).

[20] Sari, R., Mifbakhuddin, dan Kiky Y. 2010. Pengaruh Konsentrasi Ekstrak Daun Tembelakan 
(Latana camara) terhadap Kematian Larva Aedes aegypti. Jurnal Kesehatan Masyarakat Indonesia. 6 (2).

[21] Maharani, S. 2016. Uji Toksisitas Fraksi Metanol dan N-Heksan Ekstrak Daun Bintaro (Cerbera Odollam G.) terhadap Mortalitas Ulat Grayak (Spodotera Litura F.) dan Pemanfaatannya sebagai Buku Ilmiah Populer. Skripsi. Jember: Universitas Jember.

[22] Muta'ali, R., dan Indah K. 2015. Pengaruh Ekstrak Daun Beluntas (Pluchea indica) terhadap Mortalitas dan Perkembangan Larva Spodoptera litura F. Jurnal Sains dan Seni ITS, 4 (2) 23373520.

[23] Wahyuni, D., dan Loren I. 2015. Perbedaan Toksisitas Ekstrak Daun Sirih (Piper betle L.) dengan Ekstrak Biji Srikaya (Annona squamosa L.) terhadap Larva Nyamuk Aedes aegypti L. Saintifika, 17 (1) : 38-48.

[24] Kartimi, 2015. Pemanfaatan Buah Bintaro sebagai Biopestisida dalam Peanggulangan Hama pada Tanaman Padi di Kawasan Pesisir Desa Bandengan Kabupaten Cirebon. Prosiding seminar Nasional Pendidikan Biologi.

[25] Fachrur, H. 2015. Uji Efektivitas Rodentisida Nabati Ekstrak Buah Bintaro (Cerbera manghas Boiteau, Pierre L.) terhadap Hama Tikus. Skripsi. Jember: Universitas Jember.

[26] Sri, Endang. 2008. Efisiensi Parasitisasi Inang Spodoptera litura (F.) oleh Endoparasitoid Snellenius manilae Ashmead di
Laboratorium. J. HPT Tropika, 8 (1) 8-16. 